\title{
Isolation, classification and molecular characterization of bacteriophages for Enterobacter species
}

\author{
Martin J. LoesSner,* Edith NeUgirg, Ralf Zink and Siegfried SChERER \\ ${ }^{1}$ Institut für Mikrobiologie, Forschungszentrum für Milch und Lebensmittel Weihenstephan, \\ Technische Universität München, D-85350 Freising, Germany
}

(Received 3 March 1993; revised 9 June 1993; accepted 23 June 1993)

\begin{abstract}
Out of 22 Enterobacter phages investigated, nine were found to be suitable for phage typing based on their different lytic spectra on 398 strains of Enterobacter spp. isolated from milk powder and other foods. These phages were compared on the basis of morphology, protein composition, restriction endonuclease patterns and DNA-DNA hybridization. Two phages (WS-EP19, WS-EP13) belonged to the Podoviridae family (morphotype C1), and three (WS-EP20, WS-EP26, WS-EP28) were classified as Siphoviridae (morphotype B1). The other four phages were Myoviridae of the morphological groups A1 (WS-EP57) and A2 (WS-EP32, WS-EP94, WS-EP96). SDS-PAGE revealed individual protein profiles for each phage, which corresponded to different restriction enzyme fragment patterns. DNA-DNA hybridization demonstrated the close relationship of phages WS-EP20 and WS-EP26, and of WS-EP94 and WS-EP96. In general, a good correlation was found between groupings obtained with the various methods. The nine phages could be attributed to existing enterobacterial phage species although some differences to the described type phages were observed.
\end{abstract}

\section{Introduction}

Enterobacteria represent a dominant portion of the 'recontamination flora' of dairy products made from pasteurized milk (Frazier \& Westhoff, 1978; Keogh, 1971). Their presence often indicates inadequate sanitization and/or faulty construction of the processing equipment (Schmidt-Lorenz \& Spillmann, 1988). Members of the genus Enterobacter are frequently found in dried products such as milk powder. Although they are of little pathological significance, their presence may indicate low-frequency contamination by ecologically similar enterobacterial pathogens such as Salmonella.

In order to correlate Enterobacter strains isolated from contaminated products and to identify possible sources and routes of contamination, they need to be differentiated beyond the species and biovar level. Serological discrimination of 79 different serovars among the genus Enterobacter has been reported by Sakazaki \& Namioka (1960). However, this technique depends on the ready availability of more than 100 different antisera, and therefore seems unsuitable for routine typing of a large number of strains. Bacteriophage typing has often proved to be a practical and successful method for this

*Author for correspondence. Tel. +498161 713859; fax +49 8161714492. purpose (see Ackermann \& DuBow, 1987). However, no phage typing system is yet available for differentiation of Enterobacter strains.

Only very few phages for Enterobacter have been studied to any extent (Grimont et al., 1978; Popovici et al., 1976). Neither exact particle dimensions nor data regarding their proteins or DNA are available for these phages, except that three of them belong to Bradley's morphotype C3 (Grimont et al., 1978).

One aim of the present study was to isolate phages that were sufficiently specific for Enterobacter spp., and gave a high typability of strains. However, our main objective was to provide a detailed characterization and classification of these phages by electron microscopy, protein analysis, digestion of phage DNAs with various restriction enzymes and DNA-DNA hybridization.

\section{Methods}

Bacterial strains and culture conditions. Most of the 398 strains of Enterobacter spp. and most of the other enterobacteria used in this study (see Table 3) were isolated in our laboratory from milk powder and other foods (U. Schramm, unpublished results). The remaining strains were taken from the 'Weihenstephan culture collection' (WS), including the type strains of all species tested. Bacteria were cultivated on plate count (PC) agar or in PC-broth (Merck). For titration of phages, soft-agar was used (PC-broth supplemented with $0.4 \%$ agar). All strains were stored on PC-agar slants at $4^{\circ} \mathrm{C}$ and transferred bimonthly. Incubation temperature was either $30^{\circ} \mathrm{C}$ or $37^{\circ} \mathrm{C}$. 
Table 1. Enterobacter phages and corresponding propagating strains employed

\begin{tabular}{|c|c|c|c|c|}
\hline \multicolumn{2}{|c|}{ Phages } & \multicolumn{3}{|c|}{ Propagating strains } \\
\hline Code & Source & Species & Code & Source \\
\hline WS-EP19 & Sewage & Enterobacter cloacae & W009 & Minced meat \\
\hline WS-EP13 & Sewage & Enterobacter cloacae & W008 & Minced meat \\
\hline WS-EP20 & Sewage & Enterobacter cloacae & W011 & Milk powder \\
\hline WS-EP26 & Sewage & Enterobacter cloacae & W012 & Milk powder \\
\hline WS-EP28 & Sewage & Enterobacter cloacae & W012 & Milk powder \\
\hline WS-EP57 & ATCC & Enterobacter sakazakii & W212 & Milk powder \\
\hline WS-EP32 & Sewage & Enterobacter cloacae & W019 & Milk powder \\
\hline WS-EP94 & Sewage & Enterobacter cloacae & W096 & Milk powder \\
\hline WS-EP96 & Sewage & Enterobacter cloacae & W008 & Minced meat \\
\hline
\end{tabular}

Isolation and propagation of phages. A total of 21 phages was isolated from sewage and waste water by methods detailed previously (Loessner \& Busse, 1990). Briefly, aqueous samples were centrifuged, sterilefiltered, concentrated, and spotted on lawns of indicator bacteria. Phage plaques could then be picked and amplified by the soft agar double-layer method of Adams (1959). To ensure purity of the phage preparations, isolated plaques were repeatedly picked and plated.

Phage EP57 was obtained from the ATCC (American Type Culture Collection; no. 23355B-1).

High-titre phage lysates were prepared with the double-layer technique, using carefully selected propagating strains.

Determination of host range. This was done using the reversed phage typing procedure as outlined elsewhere (Loessner, 1991). Agar plates were preinoculated with the phage suspensions to be tested, carefully flooded with bacterial broth cultures, and incubated for 16-24 h. Nine of the 22 tested phages were found to differ in their lytic spectra, and were selected for further investigation (Table 1).

Virus concentration and purification. Phage concentration was done by precipitation with PEG-8000 (Sigma), essentially according to Yamamoto et al. (1970). Particles were purified on a modified CsCl step-gradient as described earlier (Loessner \& Busse, 1990; Sambrook et al., 1989).

Electron microscopy. Purified phage particles were adsorbed to thin carbon films, placed on 400-mesh copper grids (Balzers), negatively stained with $2 \%(\mathrm{w} / \mathrm{v})$ uranyl acetate, and examined in a Zeiss EM 10 electron microscope at an acceleration voltage of $80 \mathrm{kV}$. For calibration, catalase crystals (Luftig, 1967) and a standard cross grating ( $d=0.463 \mu \mathrm{m}$; both from Balzers) were used.

$S D S-P A G E$ profiles. In order to remove residual $\mathrm{CsCl}$, phage suspensions were washed with sterile, ultrapure water (Milli-Q; Millipore), pelleted at $150000 \mathrm{~g}$ for $90 \mathrm{~min}$, and resuspended in sterile water to an optical density $\left(\mathrm{OD}_{260}\right)$ of $0 \cdot 2-0 \cdot 3$. Suspensions were mixed with concentrated SDS-sample buffer and heated to $95^{\circ} \mathrm{C}$ for $5 \mathrm{~min}$. Ten microlitres of each were then analysed on an ultrathin, horizontal poregradient $(8-18 \% \mathrm{~T})$ gel (ExcelGel, Pharmacia) as reported previously (Zink \& Loessner, 1992). Proteins were stained with Coomassie R-350 (Pharmacia), and the molecular size marker SDS-7L (Sigma) was used for calibration.

Extraction of phage DNA. The standard procedure of Sambrook et al. (1989) was used. Purified DNAs were resuspended in TE buffer (10 mM-Tris, $1 \mathrm{~mm}$-EDTA, $\mathrm{pH} 8.0$ ) and stored at $-20^{\circ} \mathrm{C}$.

Restriction enzyme analysis. Purified phage DNAs were digested with restriction enzymes (see Table 5) according to the supplier's recom- mendations (United States Biochemical Corp.). Generated fragments (approx. $0.7 \mu \mathrm{g}$ total) were electrophoretically separated on $0.8 \%$ agarose gels in TAE buffer (Sambrook et al., 1989). Fragment sizes were determined from co-migrating $H$ indIII and BstEII digests of $\lambda$ DNA (Sigma).

Southern blotting and DNA-DNA hybridization. EcoRV-generated DNA fragments were vacuum blotted (VacuGene XL, Pharmacia) onto positively charged nylon membranes (Boehringer), covalently bound by UV irradiation $\left(312 \mathrm{~nm}, 0.7 \mathrm{~J} \mathrm{~cm}^{-2}\right)$, and hybridized to digoxigenin-dUTP-labelled DNA from selected phages (random primed DNA labelling kit, Boehringer). Hybridization was carried out without formamide under conditions of high stringency $[5 \times \mathrm{SSC}$ $(0.75 \mathrm{M}-\mathrm{NaCl}, 75 \mathrm{~mm}$-trisodium citrate, $\mathrm{pH} 7.0), 68^{\circ} \mathrm{C}$ ], as were the subsequent washes $\left(0.1 \times \mathrm{SSC}, 0.1 \% \operatorname{SDS}, 68^{\circ} \mathrm{C}\right)$. Chemiluminescent detection of hybridization signals was done as outlined in the manufacturer's (Boehringer) protocol, except that the X-ray film exposure times could be shortened to $30-90 \mathrm{~s}$.

\section{Results and Discussion}

\section{Phage specificity and suitability for phage typing}

Host ranges of the nine selected phages on their seven propagating strains are given in Table 2. Although WSEP26 and WS-EP28 are identical with respect to these strains, they differed by lytic activity when 447 other strains of Enterobacter spp. and other Enterobacteriaceae (Table 3) were tested with the nine phages. Interestingly, some of the phages were also able to lyse strains of Escherichia coli (WS-EP26, WS-EP28, WS-EP57, WSEP96) and Serratia marcescens (WS-EP20). This can be explained by the close relationship among the enterobacterial genera, which is reflected in the host-range of their phages (Ackermann \& DuBow, 1987). These authors also state that many enterobacterial phages are polyvalent and cross intergeneric boundaries, while still retaining some specificity and preferences. Because the phages investigated here clearly show such preferences towards the genus Enterobacter, they should be referred to as Enterobacter phages.

Table 2. Lytic spectra of Enterobacter phages on propagating strains

\begin{tabular}{cccccccc}
\hline & \multicolumn{7}{c}{ Enterobacter strains } \\
\cline { 2 - 7 } Phages & W008 & W009 & W011 & W012 & W019 & w096 & W212 \\
\hline WS-EP19 & - & + & - & - & - & - & - \\
WS-EP13 & + & - & - & - & - & - & - \\
WS-EP20 & - & - & + & + & - & - & - \\
WS-EP26 & - & - & - & + & - & - & - \\
WS-EP28 & - & - & - & + & - & - & - \\
WS-EP57 & - & - & - & - & - & - & + \\
WS-EP32 & - & - & - & - & + & - & - \\
WS-EP94 & - & - & - & - & - & + & - \\
WS-EP96 & + & - & - & - & + & + & + \\
\hline \hline
\end{tabular}

+ , Lysis; - , no lysis. 
Table 3. Phage sensitivity of 398 Enterobacter strains and 56 other Enterobacteriaceae

\begin{tabular}{lcc}
\hline \multicolumn{1}{c}{ Species } & $\begin{array}{c}\text { No. of strains } \\
\text { sensitive/no. } \\
\text { tested }\end{array}$ \\
\hline Enterobacter cloacae & $338 / 362$ & $(93 \cdot 4 \%)$ \\
Enterobacter agglomerans & $10 / 17$ & $(58 \cdot 8 \%)$ \\
Enterobacter sakazakii & $8 / 13$ & $(61 \cdot 5 \%)$ \\
Enterobacter aerogenes & $0 / 6$ & \\
Escherichia coli & $4 / 14$ & $(28.5 \%)$ \\
Serratia marcescens & $1 / 2$ & $(50 \cdot 0 \%)$ \\
Serratia liquefaciens & $0 / 7$ & \\
Klebsiella pneumoniae & $0 / 8$ & \\
Klebsiella oxytoca & $0 / 10$ & \\
Klebsiella ozaenae & $0 / 1$ & \\
Citrobacter freundii & $0 / 5$ & \\
Salmonella arizonae & $0 / 1$ & \\
Salmonella enteritidis & $0 / 1$ & \\
Salmonella infantis & $0 / 1$ & \\
Salmonella tennessee & $0 / 1$ & \\
Erwinia amylovora & $0 / 1$ & \\
Erwinia carotovora & $0 / 1$ \\
Erwinia herbicola & $0 / 1$ \\
Erwinia stewartii & $0 / 1$ \\
Hafnia alvei & $0 / 2$ \\
Proteus mirabilis & $0 / 1$ \\
Proteus vulgaris & $0 / 1$ \\
\hline \hline
\end{tabular}

More than $90 \%$ of all Enterobacter spp. strains tested were lysed by one or more phages, with the highest typability among strains of Enterobacter cloacae. However, none of our phages was able to lyse any of the six tested strains of Enterobacter aerogenes. Host ranges of the phages were found to be quite different, which makes them useful for strain differentiation (i.e. phage typing). Sixty-six different lytic patterns (phagovars) could be observed among the 356 typable strains of Enterobacter spp. The frequency of phagovars varied considerably: 31 patterns could be assigned to single isolates only, while the five most frequent phagovars were observed among $34 \%$ of the typable strains. Further attempts should be made to isolate phages able to lyse strains of $E$. aerogenes, as well as to increase the number and discrimination of typable strains. However, the Enterobacter phages isolated and described in this study constitute a useful basis for phage typing. They are freely available upon request.

\section{Phage morphology and taxonomic classification}

As shown in Fig. 1, four different morphological types were observed among the investigated bacteriophages, and could be placed into three phage families. Their exact dimensions are given in Table 4. Phages WS-EP19 and WS-EP13 are members of the Podoviridae family, and correspond to morphotype $\mathrm{Cl}$ of Bradley (1967) (see also Ackermann \& Eisenstark, 1974). Phages WS-EP20, WS-EP26 and WS-EP28 were found to belong to morphological group B1 within the Siphoviridae family. The other phages are Myoviridae. However, while WSEP57 has an isometric capsid (A1 morphotype), phages WS-EP32, WS-EP94 and WS-EP96 show slightly prolate capsids, which is characteristic for morphological group A2. The latter phages also have a clearly visible collar and long tail fibres.

Enterobacter phages may be classified using the updated scheme for morphological classification of tailed enterobacterial phages (Ackermann \& DuBow, 1987). The phages characterized here may be related to existing morphological species: WS-EP19 seems very similar to phage species sd (head diameter $69 \mathrm{~nm}$, tail length $19 \mathrm{~nm}$, many short tail fibres). Although WS-EP13 is quite similar to WS-EP19, its slightly shorter tail corresponds more to species $\mathrm{N} 4$ (head diameter $70 \mathrm{~nm}$, tail length $10 \mathrm{~nm}$ ). Enterobacter phages WS-EP20, WS-EP26, and probably WS-EP28 (capsid diameter $65 \mathrm{~nm}$, average tail length $222 \mathrm{~nm}$ ) may be related to phage species X (capsid $63 \mathrm{~nm}$, tail length $227 \mathrm{~nm}$ ), a flagella-specific phage of Salmonella, Serratia, and E. coli (H.-W. Ackermann, personal communication). WS-EP57 could be related to Citrobacter phage FC3-9 (capsid $84 \mathrm{~nm}$, tail length $115 \mathrm{~nm}$ ), although it lacks the curly lateral tail fibres described for FC3-9 (H.-W. Ackermann, personal communication). Finally, phages WS-EP32, WS-EP94 and WS-EP96 can be regarded as members of the species T4 (head dimensions $111 \times 78 \mathrm{~nm}$; tail length $113 \mathrm{~nm} ; 24$ tail striations), the type phage of the T-even bacteriophages (Ackermann \& DuBow, 1987). In fact, the protein composition of T4 is very similar to the profiles of WS-EP32, WS-EP94 and WS-EP96 (data not shown). A recent study (Maftahi, 1992) reports that $18 \mathrm{~T}$-even type phages investigated fall into 6 serological and DNA homology groups. It would be interesting to see if the two homology groups described here (see below) could be assigned to any of these groups.

\section{Protein composition of phage particles}

Electrophoretic profiles of phage structural proteins have repeatedly been found to be a very useful means of phage differentiation and characterization (Coveney $e t$ al., 1987; Mata et al., 1986; Stewart et al., 1985; Zink \& Loessner, 1992), and allow for both the distinction of individual phages and the establishment of groups. SDSPAGE profiles of the Enterobacter phage structural proteins are presented in Fig. 2. Protein compositions are different for each phage, although some similarities with respect to number and size of major protein bands can be seen. These clusters (e.g. WS-EP20 and WS-EP26; WSEP94 and WS-EP96) correspond well to the results of 

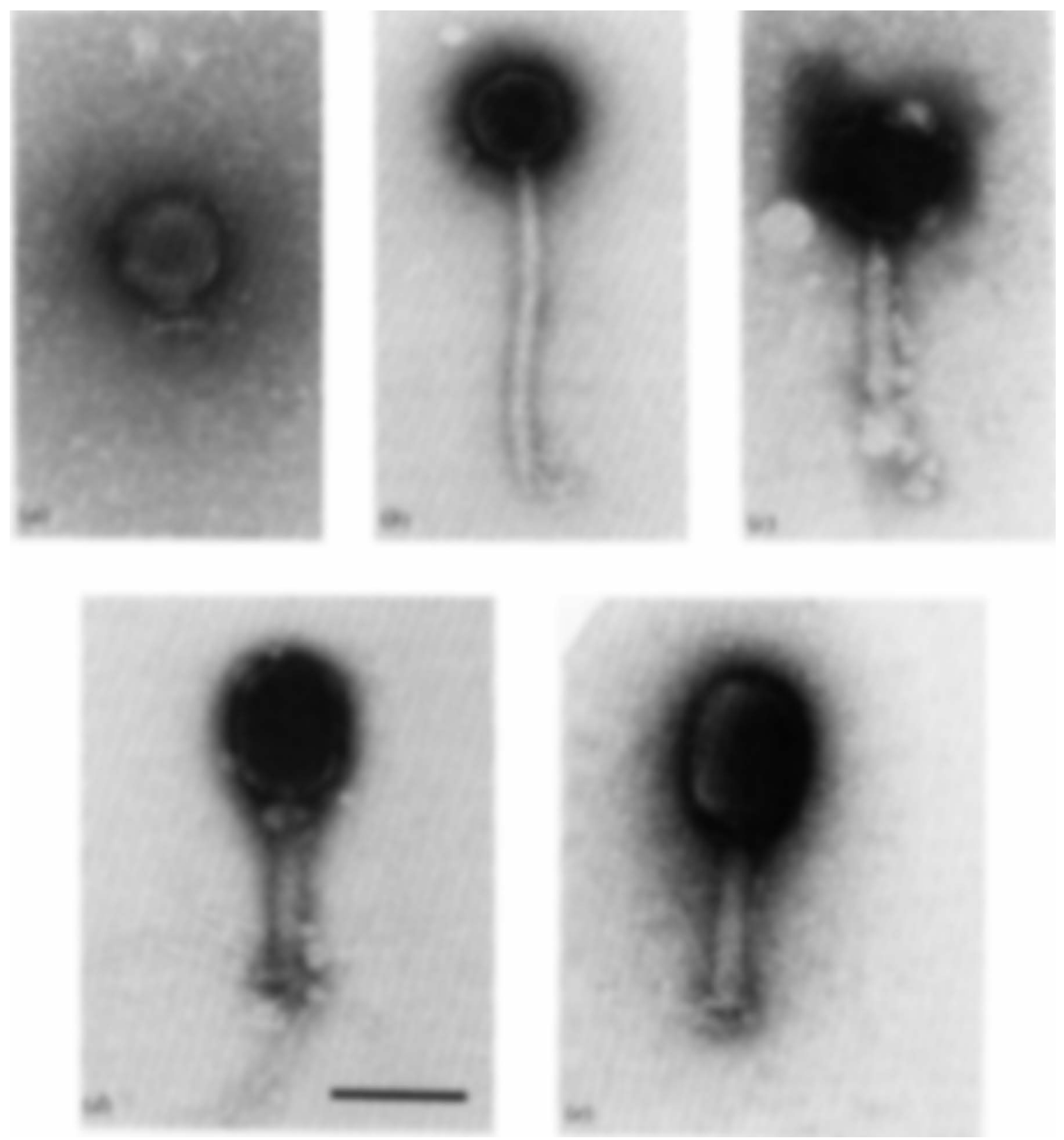

Fig. 1. Electron micrographs of Enterobacter phages of different morphotypes. Bar, $100 \mathrm{~nm}$. (a) WS-EP19; (b) WS-EP20; (c) WS-EP57; (d) WS-EP32; (e) WS-EP94.

restriction enzyme analysis and DNA-DNA hybridization, as demonstrated later.

However, protein compositions should be interpreted with care, since even completely different phages may possess structural proteins of a comparable size [see Fig. 2, lane D (WS-EP26) and lane F (WS-EP57)]. On the other hand, phages of a similar morphology may show notably different protein profiles [see Fig. 2, lane A (WSEP19) and lane B (WS-EP13)]. Therefore, protein analyses seem to be most useful for comparison of morphologically similar phages. In addition, all visible protein bands should be compared, since the minor bands in particular enable the differentiation of closely related phages.

\section{Restriction endonuclease patterns of phage DNAs}

Table 5 summarizes the results of restriction enzyme analysis of the nine Enterobacter phage DNAs. All but one DNA were digested by EcoRV (Fig. 3). As expected 
Table 4. Morphology and dimensions (in $\mathrm{nm}$ ) of Enterobacter phages studied

\begin{tabular}{ccrrccc}
\hline & & & \multicolumn{4}{c}{ Tail } \\
\cline { 5 - 6 } Phage & Morpho- & & & \\
type & Capsid & Length & Diameter & Contractile & $n^{*}$ \\
\hline WS-EP19 & C1 & $70 \pm 3$ & $20 \pm 2$ & $12 \pm 2$ & no & 6 \\
WS-EP13 & C1 & $68 \pm 3$ & $12 \pm 2$ & $12 \pm 2$ & no & 5 \\
WS-EP20 & B1 & $65 \pm 2$ & $225 \pm 8$ & $13 \pm 1$ & no & 6 \\
WS-EP26 & B1 & $65 \pm 2$ & $220 \pm 8$ & $14 \pm 1$ & no & 8 \\
WS-EP28 & B1 & $68 \pm 2$ & $217 \pm 8$ & $14 \pm 1$ & no & 6 \\
WS-EP57 & A1 & $82 \pm 3$ & $127 \pm 4$ & $20 \pm 2$ & yes & 7 \\
WS-EP32 & A2 & $113 \times 83 \pm 3$ & $112 \pm 3$ & $22 \pm 2$ & yes & 9 \\
WS-EP94 & A2 & $111 \times 84 \pm 3$ & $113 \pm 3$ & $21 \pm 2$ & yes & 8 \\
WS-EP96 & A2 & $111 \times 82 \pm 3$ & $113 \pm 3$ & $21 \pm 2$ & yes & 8 \\
\hline \hline
\end{tabular}

${ }^{*} n$, Number of measured particles.

Fig. 2. SDS-PAGE $(8-18 \% \mathrm{~T})$ electrophoretic profiles of Enterobacter phage structural proteins. Lanes $7 \mathrm{~L}$, molecular size standard. Other lanes: A, WS-EP19; B, WS-EP13; C, WS-EP20; D, WSEP26; E, WS-EP28; F, WS-EP57; G, WS-EP32; H, WS-EP94; I, WS-EP96.

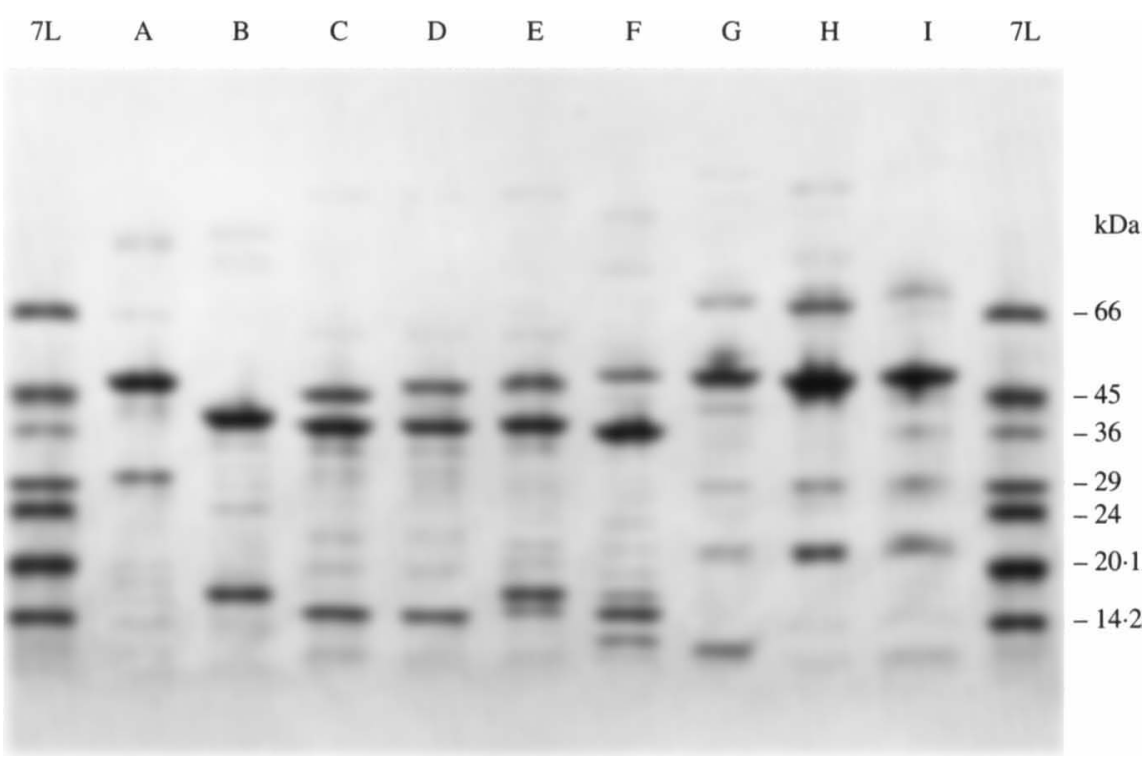

Table 5. Restriction enzyme analysis of Enterobacter phage genomes

\begin{tabular}{ccccccc}
\hline & \multicolumn{6}{c}{ No. of fragments detected after digestion with: } \\
\cline { 2 - 7 } $\begin{array}{c}\text { DNA from } \\
\text { phage }\end{array}$ & HindIII & BamHI & EcoRI & EcoRV & KpnI & SacI \\
\hline WS-EP19 & - & - & - & 19 & - & - \\
WS-EP13 & 10 & 13 & 9 & 21 & 10 & - \\
WS-EP20 & - & - & - & 2 & $\geqslant 35$ & - \\
WS-EP26 & - & - & - & 4 & 23 & - \\
WS-EP28 & - & 12 & 18 & 17 & $\geqslant 35$ & - \\
WS-EP57 & $\geqslant 30$ & - & - & $\geqslant 35$ & - & - \\
WS-EP32 & - & - & - & - & - & - \\
WS-EP94 & - & - & $\geqslant 35$ & $\geqslant 35$ & - & - \\
WS-EP96 & - & - & $\geqslant 35$ & $\geqslant 35$ & - & - \\
\hline \hline
\end{tabular}

from the results of protein analysis, no identical fragment patterns could be observed. Nevertheless, some similarities were detected (see Table 5; WS-EP20 and WSEP26; WS-EP94 and WS-EP96). These were not hostdependent (restriction/modification systems), since the phages in question were propagated on different strains (see Table 1). Phages WS-EP32, WS-EP94 and WS-EP96 are morphologically very similar to coliphages of the Teven type. Therefore, it may be assumed that the resistance of their DNA (especially WS-EP32) to most tested restriction enzymes is due to phage-encoded modification and/or glycosylation of bases (Warren, 1980), rather than the lack of recognition sites within their quite large genomes.

Approximate sizes of some phage genomes could be calculated from fragment lengths for phage WS-EP13 $(48 \mathrm{~kb})$, WS-EP26 $(61 \mathrm{~kb})$ and WS-EP28 $(63 \mathrm{~kb})$.

\section{DNA homologies correlate well with morphology and} protein profiles

Digoxigenin-labelled random primed DNAs from four phages (selected according to morphological group) were hybridized to EcoRV-generated fragments of all investigated phages (Fig. 4). DNA from phage WS-EP19 did 


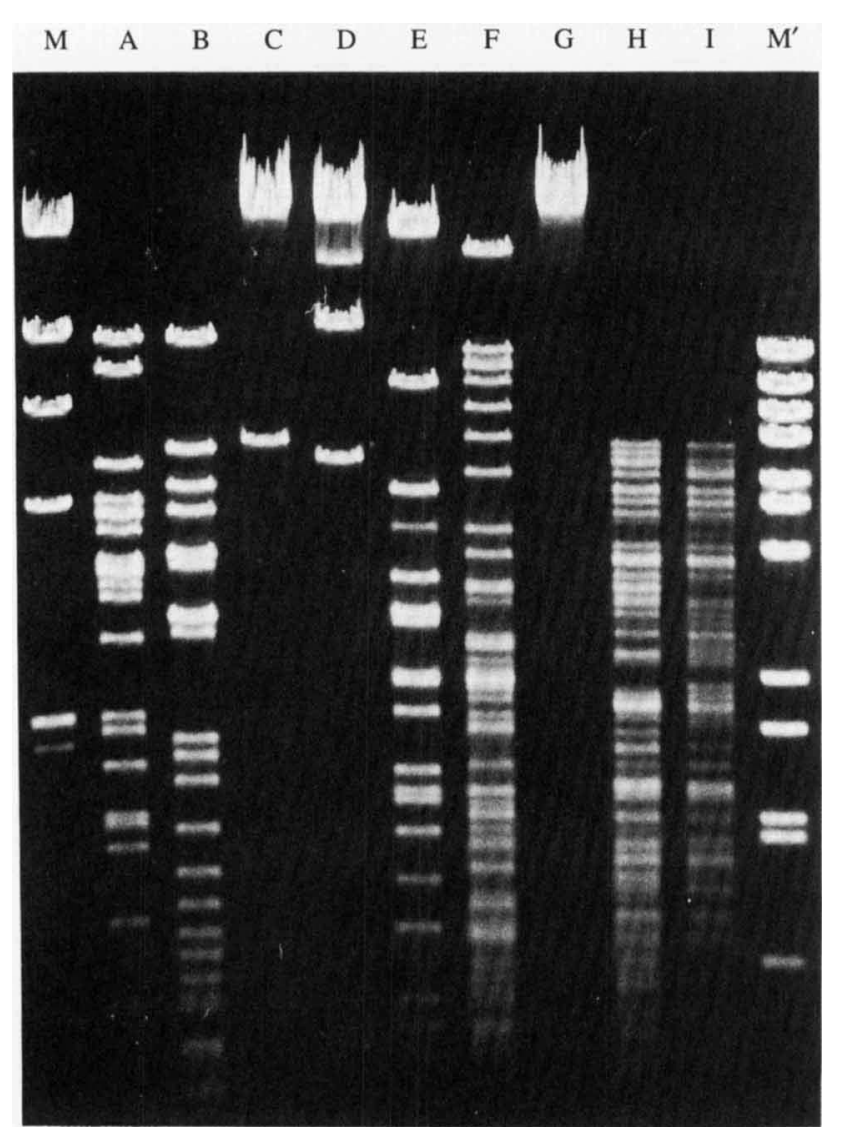

Fig. 3. Agarose gel electrophoresis patterns of EcoRV-generated fragments of phage DNAs. Molecular size standards: lane $M, \lambda$ HindIII digest; lane $\mathbf{M}^{\prime}, \lambda$-BstEII digest. Other lanes: A, WS-EP19; B, WS-EP13; C, WS-EP20; D, WS-EP26; E, WS-EP28; F, WS-EP57; G, WS-EP32; H, WS-EP94; I, WS-EP96.

not hybridize with any other DNA, indicating a lack of homology at the DNA level, even to the morphologically similar phage WS-EP13. This was not surprising, considering their extremely different protein profiles.

All fragments of WS-EP26 were detected by labelled WS-EP20 DNA, underlining the close relationship of these two phages, which has already been shown by SDSPAGE and electron microscopy. No signal was observed with WS-EP28, despite their similar morphology and host range. However, protein profiles and restriction enzyme analyses suggested their unrelatedness at this low level.

As expected, WS-EP57 DNA hybridized with itself only, confirming the unique characteristics of this phage.

Cross-hybridization using WS-EP94 DNA as a probe revealed extensive homology to WS-EP96, and no signal was seen with WS-EP32. As in WS-EP28, protein composition and resistance to endonucleases set WSEP32 apart from WS-EP94 and WS-EP96, despite essentially identical morphology.

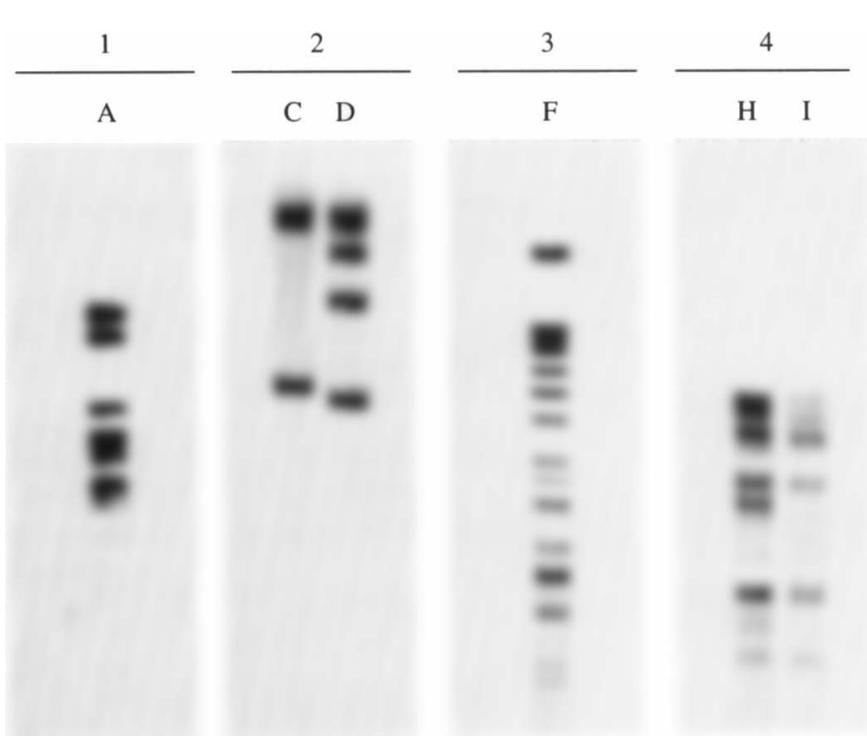

Fig. 4. Southern blots of EcoRV DNA fragments of Enterobacter phages and hybridization with digoxigenin-labelled DNAs of phages WS-EP19 (1); WS-EP20 (2); WS-EP57 (3); WS-EP94 (4). Letters correspond to the lanes in Fig. 3.

Correlations between DNA homology, structural proteins and, to a lesser extent, particle morphology were also found by a number of other workers within various bacteriophage groups (Arendt et al., 1991; Braun et al., 1989; Mata et al., 1986; Prévot et al., 1989; Stewart et al., 1985). Therefore, it can be concluded that at least those genetic elements encoding major structural proteins are well conserved within each 'group' of similar phages. However, these groups or species should be defined by DNA homologies (Grimont \& Grimont, 1981) or, if at all possible, protein sequences.

We wish to thank H.-Ch. Bartscherer (Freising, Germany) for providing the electron microscopy facility. We are indebted to $H$.W. Ackermann (Quebec, Canada) for his critical comments and valuable help in preparing this manuscript.

\section{References}

ACKermanN, H.-W. \& DuBow, M. S. (1987). Enterobacterial phages. In Viruses of Procaryotes, vol. I: General Properties of Bacteriophages, pp. 143-150; vol. II: Natural Groups of Bacteriophages, pp. 85-100. Boca Raton: CRC Press.

ACKermanN, H.-W. \& Eisenstark, A. (1974). The present state of phage taxonomy. Intervirology 3, 201-219.

ADAMS, M. H. (1959). Methods of study of bacterial viruses. In Bacteriophages, pp. 443-457. New York: Interscience publishers.

ARendT, E. K., LonVaud, A. \& Hammes, W. P. (1991). Lysogeny in Leuconostoc oenos. Journal of General Microbiology 137, 2135-2139.

BRADLEY, D. E. (1967). Ultrastructure of bacteriophages and bacteriocins. Bacteriological Reviews 31, 230-314.

Braun, V., JR, Hertwig, S., Neve, H., Geis, A. \& Teuber, M. (1989). Taxonomic differentiation of bacteriophages of Lactococcus lactis by 
electron microscopy, DNA-DNA hybridization, and protein profiles. Journal of General Microbiology 135, 2551-2560.

Coveney, J. A., FitzGerald, G. F. \& Daly, C. (1987). Detailed characterization and comparison of four lactic streptococcal bacteriophages based on morphology, restriction mapping, DNA homology, and structural protein analysis. Applied and Environmental Microbiology 53, 1439-1447.

Frazier, W. C. \& Westhoff, D. C. (1978). Food Microbiology. 3rd edn. New York: McGraw-Hill.

GrImont, F. \& GRIMONT, P. A. D. (1981). DNA relatedness among bacteriophages of the morphological group C3. Current Microbiology 6, 65-69.

Grimont, F., Grimont, P. A. D. \& du Pasquier, P. (1978). Morphological study of five bacteriophages of yellow-pigmented enterobacteria. Current Microbiology 1, 37-40.

KEOGH, B. P. (1971). Reviews of the progress of dairy science. Journal of Dairy Research 38, 91-111.

LOESSNER, M. J. (1991). Improved procedure for bacteriophage typing of Listeria strains and evaluation of new phages. Applied and Environmental Microbiology 57, 882-884.

LOESSNER, M. J. \& BUSSE, M. (1990). Bacteriophage typing of Listeria species. Applied and Environmental Microbiology 56, 1912-1918.

LuFTIG, R. (1967). An accurate measurement of the catalase crystal period and its use as an internal marker for electron microscopy. Journal of Ultrastructure Research 20, 91-102.

MAFTAHI, M. (1992). Etude moléculaire comparative de 18 bactériophages appartenant au morphospecies T-pair. Thesis (DEA), Universités Paris $\mathrm{V}$ and $\mathrm{XI}$.

Mata, M., Trautwetter, A., Luthaud, G. \& Ritzenthaler, P. (1986). Thirteen virulent and temperate bacteriophages of Lactobacillus bulgaricus and Lactobacillus lactis belong to a single DNA homology group. Applied and Environmental Microbiology 52 , 812-818.

Popovici, M., Cosman, M., Filipescu, S., Voicescu, V. \& Olinescu, E. (1976). Taxonomic relationships Klebsiella-Enterobacter investigated by means of phage-bacteria systems. Archives Roumaines de Pathologie Expérimentale et de Microbiologie 35, 187-194.

Prevot, F., Relano, P., Mata, M. \& Ritzenthaler, P. (1989). Close relationship of virulent bacteriophages of Streptococcus salivarius subsp. thermophilus at both the protein and the DNA level. Journal of General Microbiology 135, 3337-3344.

SAKAZAKI, R. \& NamioKA, S. (1960). Serological studies on the Cloaca (Aerobacter) groups of enteric bacteria. Japanese Journal of Medical Science and Biology 13, 1-12.

Sambrook, J., Fritsch, E. F. \& Maniatis, T. (1989). Molecular Cloning: A Laboratory Manual, 2nd edn. Cold Spring Harbor, NY: Cold Spring Harbor Laboratory Press.

SCHMidT-LoReNZ, W. \& SpillmanN, H. (1988). Kritische Überlegungen zum Aussagewert von E. coli, Coliformen und Enterobacteriaceen in Lebensmitteln. Archiv für Lebensmittelhygiene 39, 3-15.

Stewart, P. R., Waldron, H. G., Lee, J. S. \& Matthews, P. R. (1985). Molecular relationships among serogroup B bacteriophages of Staphylococcus aureus. Journal of Virology 55, 111-116.

WARREN, R. A. J. (1980). Modified bases in bacteriophage DNAs. Annual Reviews in Microbiology 34, 137-158.

Yamamoto, K. R., Alberts, B. M., Benzinger, R., LAWHorne, L. \& Treiber, G. (1970). Rapid bacteriophage sedimentation in the presence of polyethylene glycol and its application to large-scale virus purification. Virology 40, 734-744.

ZINK, R. \& LOESSNER, M. J. (1992). Classification of virulent and temperate bacteriophages of Listeria spp. on the basis of morphology and protein analysis. Applied and Environmental Microbiology 58, 296-302. 